\title{
Hans Morgenthau, Realist Theory of International Leadership, and the Future of Global Order
}

\author{
Biao Zhang ${ }^{1}$ (D)
}

Received: 5 September 2017/Accepted: 7 September 2017/Published online: 13 September 2017

(C) Fudan University and Springer Nature Singapore Pte Ltd. 2017

\begin{abstract}
This article argues that IR scholars can use Hans Morgenthau's work as a resource for developing a 'classical realist theory of international leadership', helping them understand the nature and impact of international leadership, especially the future of world order in which the US is believed to be abandoning its global leadership under the Trump presidency. This article first introduces the political and intellectual context in which Morgenthau develops his realist thoughts on international leadership. Then, it elaborates Morgenthau's account of how international leadership is depended on the qualities of political leadership, namely, that international leadership requires political leaders to display intellectual, moral, and practical virtues. These include wisdom, foresight, judgment, prudence, willingness, determination, courage, restraint, skill, leadership, governance, and persuasion. Finally, it argues that the dean of classical realism provides a theoretical tool that enables a more 'realistic' analysis of the future of world order, showing the deficiencies of the liberal vision that US withdrawal from the international arena under the Donald Trump presidency will necessarily create chaos and a leaderless world. This article concludes that the liberal bias against Trump has made it almost impossible to undertake a realistic assessment, and Morgenthau's writing can provide considerable insight into the problem of international leadership.
\end{abstract}

Keywords Morgenthau · International leadership · Donald Trump · Classical realism

Biao Zhang

biaozhang@cupl.edu.cn

1 International Relations, School of Political Science and Public Administration, China University of Political Science and Law, No. 7 Fuxue Road, Beijing, People's Republic of China 


\section{Introduction}

Can classical realism help international relations (IR) scholars understand the nature and impact of international leadership, especially the future of world order, at a time when the US is believed to be abandoning its international leadership under the presidency of Donald Trump? ${ }^{1}$ This article argues that Hans Morgenthau, the leading classical realist, and the founding father of the discipline can provide insight into this question (Hoffmann 1987, 6). This article is divided into five sections. The first section introduces the political and intellectual contexts in which Morgenthau develops his realist theory of international leadership, outlining his key arguments and highlighting the main theoretical features while offering a comparison with other three prominent theories of international leadership (the theories of hegemonic war, liberal hegemony, and hegemonic stability in Gilpin 1981, 1988; Modelski 1978, 1987; Organski and Kugler 1981; Ikenberry 2011; Ruggie 1982; Kindleberger 1981, 1987; Krasner 1976). The following three sections elaborate Morgenthau's theory of international leadership: international leadership requires political leaders to display intellectual, moral, and practical virtues. These include wisdom, foresight, judgment, prudence, willingness, determination, courage, restraint, skill, leadership, governance, and persuasion. The final section incorporates Morgenthau's approach into an analysis of the prospect of world order under the Trump presidency. It argues that classical realism provides a theoretical tool that enables a more 'realistic' analysis of the future of world order, showing the deficiencies of the liberal vision that US withdrawal from the international arena under the Donald Trump presidency will necessarily create chaos and a leaderless world.

\section{Mapping Morgenthau's Location within Theories of International Leadership}

To understand Morgenthau's theory of international leadership, the best place to begin is with the political context which played a prominent role in shaping his thinking: the Cold War (Thompson 1960; Myers 1997; Nobel 1995; See 2001; Craig 2003, 93-116; Cox 2007). Morgenthau recognized that the US, in emerging from the Second World War as the most powerful country in global affairs, was immediately confronted by a dual challenge.

The main challenge was presented by the Soviet Union. The Soviet Union's expanding influence in the European continent after the war, its support of communist takeover, and its acquisition of nuclear weapons later in 1949 posed a clear and deadly threat to the US. The spread of communism from Europe to Asia (as embodied by "the loss of China") also resulted in a substantial increase of communist influence, thus drastically altering the regional balance of power. Morgenthau maintained that the US was being encroached upon from both Europe

\footnotetext{
${ }^{1}$ Due to space limitations, I make reference to Morgenthau's collections of political writings-In Defense of the National Interest, Politics in the Twentieth Century (three volumes) and Truth and Power-rather than the original individual essays.
} 
and Asia. The security that the US had enjoyed in the Western Hampshire prior to the Second World War appeared to once again be in danger.

The other challenge was internal-it came from the American political tradition and its institutional structures. The American political tradition was pulling US postwar foreign policy towards two "extreme" directions, neither of which could respond adequately to the external Soviet/communist challenge (Morgenthau 1952). One extreme was isolationism. This current sought to direct American foreign policy towards hemispheric isolation from the European continent (e.g., R.A. Taft, see Thompson 1960, 186-8). The other current was liberal internationalism. This sought to establish international organizations that would integrate the Soviet Union into the new order (e.g., final term FDR). Both currents within American political thought tended to overlook the growing danger. ${ }^{2}$ While both currents were deficient in relation with the growing threat, the American democratic constitution presented an even more serious problem. Morgenthau maintained that the American democratic constitution inhibited the ability to conduct foreign policy in a world of hostile communist/totalitarian states: democracies could easily become the victim of their own existential weakness because of the fragmentation of authority and weak presidential leadership (Morgenthau 1951, 225; Jervis 1984, 872). He saw a parallel between the postwar world and the European democracies in the 1930s, but maintained that the ultimate outcome could be worse than Munich. He feared that the US, lacking the "institutional excellence of the British [parliamentary system]" would invite aggression, succumbing to blunders worse than those perpetrated by Chamberlain during the late 1930s (Morgenthau 1948, 108; Scheuerman 2009, 178-9).

It was against this backdrop that Morgenthau developed his theory of international leadership. Although he never used the term 'international leadership', Morgenthau sought to address the issue in a substantive and sophisticated way.

First, Morgenthau argued that in the aftermath of the Second World War, the US must assume the role of a number one power in the international system. A number one power meant a power that recognized its unparalleled material capability, defined its interest and responsibility in global terms, and assumed the lead in preventing a decisive shift in the global balance of power and defending against challenges by aspiring hegemons in key regions (Nye 2008, 64). Morgenthau argued that international leadership implied two tasks. Politically, the most important task was to assume the role of an offshore balancer: this would entail maintaining a stable balance of power in both Europe and Asia, and organizing the democracies with a view to checking Soviet expansion and aggression (Mearsheimer 2001, 41-2). In acting at a moral level, Morgenthau (1960) argued that the US must strive to ensure that the "American purpose of politics" prevailed over communism. By virtue of the fact that the fortunes of democracy and Western civilization was dependent on its moral leadership, the US must take the lead in defending the values of freedom, while taking care to ensure that, in acting thus, it did not transform itself

\footnotetext{
${ }^{2}$ Later Morgenthau became increasingly concerned with the danger of over-balancing the Soviet threat. His apprehension about the universalistic aspiration became stronger when, for instance, the strategy of "massive retaliation" was announced in the early 1950 s.
} 
into a garrison state with a 'top-heavy' national security apparatus that ultimately acted to the detriment of the liberal purposes it sought to defend (Klusmeyer 2010). The US must accomplish both tasks. It would be disastrous if the US was defeated in the military or moral battleground.

Second, Morgenthau viewed, in drawing on the thoughts of Max Weber, that international leadership was largely dependent on qualities of political leadership (see esp. Turner 2009, 76-9; Turner and Factor 1984, 64-9; Thompson 1984; Williams 2005). ${ }^{3}$ International leadership was dependent on whether political leaderships could externally discern aggressive intention, anticipate the adversary's reaction, and make circumspect decisions, and internally implement policy that effectively responded to threats, convince people about the necessity of scarifying themselves for the rightful cause, and exercise statecraft that gained broad public support. Morgenthau acknowledged the significance of material capability: he recognized that even if it was weakened by "poor statecraft" and "mediocre diplomacy", the US could still punch fairly heavily by virtue of its substantial reserves of material power (Morgenthau 1948, 108). However, he did see that political leadership played a decisive role in sustaining international leadership. Morgenthau insisted that the qualities of political leadership could almost determine the fate of international leadership (see similarly the literature on the influence of political leadership on foreign policy, institutional bargaining, and power redistribution in Byman and Pollack 2001; Greenstein 2000; Ikenberry 1996, 395-8; Quinn 2011; Yan 2016; Young 1991).

Third, Morgenthau drew mainly on the Ancient Greek thinkers to define what qualities of leadership would need to be exhibited. Morgenthau underscored, under the influence of Aristotle, "practical wisdom" ("prudence"), "foresight", "political art", and moral "determination" as opposed to akrasia (see Brown 2012; Lang 2007; Molloy 2009; Ringmar 2014, 14). He followed the Greek Tragedians to stress the importance of "decisiveness" and "humility", warning against the danger of hubris (Morgenthau 1962a, 326, 1978, 11; Lebow 2003, 2009). He praised the greatest statesman as an approximation to Plato's philosopher king who evidenced substantial reserves of "knowledge" and "wisdom" (Morgenthau 1962c, 67). He drew attention to "what Machiavelli called virtue", which he defined as the "quality of our wills and minds" (Morgenthau 1960, 323). In addition to the classical thinkers, Morgenthau also followed Weber to stress the importance of "moral conviction", "objectivity", and "responsibility" for the statesperson (Morgenthau 1970, 68-70; Turner 2009; Myers 1997, 259). His conception of "prudence" also had strongly Burkean connotations (Morgenthau 1954; Hoy 1958, 246; Murray 1996). ${ }^{4}$ Morgenthau's account of qualities of leadership, in short, was built on the vocabulary of virtue (see similarly Gaskarth 2011).

\footnotetext{
3 On Weber's influence on Morgenthau, see further Barkawi (1998).

4 Notice that the Burkean conception of prudence has a strong empirical connotation that downplays the importance of intellect. And it seems that Morgenthau tends to associate prudence more with Burke than with Aristotle. Thompson $(1960,222)$ indicates that Morgenthau's conception of "humility" has Christian-ethical origin. See the most comprehensive account of the languages of virtue in MacIntyre 2007.
} 
Morgenthau's theory, which stressed the relationship between political leadership and international leadership at times of challenge, evidenced several features that could be compared with some later theories of international leadership.

First, Morgenthau understood international leadership with reference to the tasks of 'security/political order stabilizer' and 'moral leader'. Morgenthau defined international leadership as the tasks that sought to (a) maintain systematic stability against change and serve as a bulwark against aggression by the potential hegemon in key regions and (b) exemplify the moral purposes of Western democracy and civilization (see Morgenthau 1960, 177-88, on "free world order"). ${ }^{5}$ Morgenthau did not define international leadership with reference to the stabilization of the economy, i.e., the ability to govern international economic infrastructure using preponderant power to provide public goods for others to free ride, pay more than the pro rate share of cost or impose a preference of open trade on other states (Kindleberger 1981, 248-53; Krasner 1976; Lake 1993). Nor did he equate international leadership with the military-technological capability to prevail over the opponent during the course of an amoral contest for world domination (Gilpin 1981). Morgenthau instead argued that the US political leadership should assume international political and moral leadership. In so doing, it demanded political leaders to manifest political wisdom, moral determination, and the ability to execute foreign policy.

Second, Morgenthau's focus was always on how to use national power to preserve the political status quo and defend the moral value. In contrast to the hegemonic theorists' focus on how cyclical replacement of declining hegemons by rising challengers through the application of large-scale violence occurred, Morgenthau concentrated on the preservation of a leading state's position against challenge (Gilpin 1981, 197-202; Organski and Kugler 1981; Modelski 1978, 217-24). Thus, Morgenthau (1955) situated his theory of international leadership within the "conservative school". Furthermore, in contrast to the liberal hegemony theorists who considered institutionalization to be the best way through which existing power relations could be preserved, Morgenthau viewed national power as the foundation of international leadership (cf. Ikenberry 1996, 389-95, 2001, 50-79). He conceived of national power as the first and foremost means through which to protect itself and other countries from military aggression and moral subversion. This made him place greater emphasis on national power, and the intellectual and practical virtues that were related to the conversion of resources into different forms of powers that could be applied and employed in different situations_-such as acumen and sophisticated skills to mobilize material and ideational resources (e.g., persuading people to act).

Third, Morgenthau argued that it was the responsibility of political leadership to employ a wide range of means/strategy to fend off a powerful challenger while offsetting the threat of large-scale war. While many hegemonic war theorists considered the periodic large-scale use of violence to be the main means through which contestation could be resolved, Morgenthau argued that the question of how

\footnotetext{
${ }^{5}$ Morgenthau's idea of what international leadership entails is quite close to that of the liberal hegemony theorists.
} 
to maintain one's international leadership against the opponent's aggression and challenge depended to a far greater extent on diplomatic maneuver, political pressure, and sometimes even compromise and accommodation (see Gilpin 1981, 187-210; Modelski 1987; Organski and Kugler 1981). ${ }^{6}$ For instance, Morgenthau endorsed the idea of a "negotiated settlement" with the Soviets which would be essential to contain their expansion within the given sphere of influence. He believed that the nuclear age put more demand on political leaders to use nonviolent means: nuclear weapons changed the structural condition of international politics; stockpiles of nuclear arms meant that superpower war with nuclear exchange was no longer a viable instrument of statecraft. ${ }^{7}$ Only a political leadership that exhibits prudence and moral restraint can fend off aggression and challenge without triggering a nuclear war.

Fourth, scholars must assume the responsibility of developing a theory that helped political leaderships to cultivate/nurture these virtues. For Morgenthau, social-scientific (e.g., psychological or neurobiological) approaches to international leadership that studied the influence of leadership traits on foreign policy were misleading, because they aimed to formulate timeless/universal hypothetical laws, discover causal connections, and use history as a database for hypothesis testing (e.g., McDermott and Hatemi 2014). On the contrary, a theory of international leadership should educate the political leadership, helping nurture the virtues that were indispensable to flourish in various political situations; it should use history to teach lessons and enhance reflections (Brown 2012; McCourt 2012, 34-6). This was the ethics of scholarship. A realist theory of international leadership should aim to induce political leadership to take on certain qualities, thereby changing the status and direction of American foreign policy.

In the following discussion, I elaborate several key qualities that Morgenthau repeatedly exhorted the American political leadership to display. These virtues should be taken to be indicative rather than exhaustive. They include intellectual virtues like wisdom, judgment, and prudence; moral virtues like courage and determination; and practical virtues like leadership, governance, and persuasion.

\section{Morgenthau on the Intellectual Qualities}

The cardinal virtue that political leadership should exhibit was "political wisdom" (Morgenthau 1951, 3). ${ }^{8}$ For Morgenthau, political wisdom was the tendency to: (a) understand politics in terms of (the conflict and compromise of) national interest and (the distribution and balance of) power; (b) grasp the 'contextual nature' of interest and power; and (c) calculate how one's interest and power were affected in

\footnotetext{
${ }^{6}$ Morgenthau would be disturbed if he found someone arguing, for instance, that "a hegemonic war is characterized by the unlimited means employed" (Gilpin 1981, 200).

7 Craig argues that Morgenthau changes his position on nuclear weapons later (Craig 2003, p. 116, calls it a form of "intellectual suicide"), see also Scheuerman (2009, $123 \mathrm{ff})$.

8 In fact, "political wisdom" is a master/mother virtue to all virtues: it is the combination of intellectual, moral and practical virtues. I use it here in an intellectual sense, i.e. political wisdom understood as intellectual understanding.
} 
particular circumstances - this emphasized flexibility at the expense of rigid rules of conduct. American political leaderships that were possessed of political wisdom, for instance, would be wary of the conflict of interest between the US (a stabilizer of regional security) and the Soviet Union (a revolutionary actor). They would be aware that the US national interest, which was contingent on a global balance of power, was jeopardized if the American leadership allowed its opponent to dominate Europe and Asia.

The failure to display political wisdom not only endangered the US' international leadership but also imperiled its very existence. Moralism was decried by Morgenthau $(1951,33)$ as a clear "intellectual error" that sought to make sense of events with reference to a universal common good, thus identifying the interest and security of the state with that of mankind or democracy in the process (e.g., Woodrow Wilson's pursuit for a world "safe for democracy"). Utopianism was an error that gave rise to the misconception that a leading state could maintain order and peace by abolishing the balance of power and spheres of influence while incorporating the challenger into a new order through the establishment of international institutions. An example was FDR's attempt to organize the 'four police' and devotion of his final years to the UN, while Stalin was seeking to expand Soviet influence in Europe at the same time (Morgenthau 1969, 59-60). Isolationism, meanwhile, sought to 'protect' the US from any entanglement of foreign affairs. It was flawed because it eventually left the challenger (whether Hitler's Germany, Imperial Japan or Stalin's Russia) to dominate a key region, thus giving rise to further aggression. McCarthyism was an "intellectual failure" that derived from an inability to grasp that the main threat to American security was external (e.g., Soviet) and derived from a standing army and developing nuclear weaponry capability, rather than internal and from treason (Morgenthau 1960, 156-7). In the absence of political wisdom, in short, political leaderships would misunderstand the situations.

Second, political leaderships should exhibit "foresight". Morgenthau (1948, 153, $1951,139,1970,177)$ understood foresight to entail the ability to see ahead and take the long-term view: leaderships would need to anticipate the adversary's action, analyze emerging threats, address new configurations of interest emerging from the current situation, and accordingly prepare themselves for future threats (also see Keohane 2005, 711). Morgenthau praised Winston Churchill for anticipating in advance that the Soviet Union would dominate Europe after the defeat of Germany. He argued that had the American leaders displayed similar foresight, they would have waged the war with a view to establishing a new balance of power between the US and USSR after the war (Morgenthau 1951, 32): American military force should have been projected as far east as possible, thus protecting Eastern Europe and even Germany from Soviet occupation near the end of the war. In the late 1950s, he also criticized the American leadership for failing to anticipate the danger that the USSR may attempt to take advantage of rapidly developing technology (missile gap) by undertaking more aggressive moves. In the absence of foresight, leaders would find themselves in unprepared situation and would be caught by surprise. Morgenthau (1970, 175) stressed that foresight was a virtue that was indispensable for 
leaderships to prepare themselves for challenges, but was hard to instill within democratic societies.

Third, political leaderships should exhibit "judgment". Morgenthau understood judgment as something related to the ability to base decisions on (a) the careful calculation of one's own objectives and power resources; (b) an evaluation of the challenger's intention and capability (to harm); (c) a correct understanding of the nature and complexity of challenge (e.g., whether a challenge corresponded to a radical shift in the balance of power); (d) the ability to discern a compatibility between the individual's and opponent's objectives and assess whether the distribution of power was favorable to one's aim; and (e) an understanding of when to stand firm and when to accommodate opponents, namely, to avoid "politically unwise" concessions that might compromise a vital interest (quotation from Morgenthau 1951, 137; see further Lang 2004, 34, 59, 2013). Any failure to exhibit these qualities would lead to defeat and destruction. During the Cold War, Morgenthau repeatedly warned the American leadership against the danger of overestimating US capability and underestimating the Soviet threat: he warned that Khrushchev's "peaceful coexistence" only shifted the battleground to technology and production; the aggressive nature of Soviet foreign policy had not fundamentally changed in the aftermath of the Cuba Missile Crisis (Morgenthau 1970, 175). In the absence of judgment, the political leadership could easily misperceive the nature of threat and underbalance rising power.

Fourth, the political leadership should exhibit virtues that manifested certain styles of decision. Morgenthau placed these virtues under the headings of "decisiveness" (quick decision without hesitation) and "prudence" (weighing up the costs and benefits of one course of action against that of another or using force in a scrupulous and restraint way). These virtues were essential for a state to make quick and decisive responses to challenges, and avoid risks or unnecessary sacrifices. In the absence of decisiveness, the leadership would be confronted by an indeterminate number of potential choices. Morgenthau maintained, for example, that Kennedy was plagued by his indecisiveness - the poorly organized invasion of Cuba and hesitation over Laos both exemplified his inadequate response to communist aggression.

Each of these intellectual virtues-political wisdom, foresight, judgment, and prudence-is central to the maintenance of the balance of power against aggression. The failure to display these virtues would make the leadership unable to recognize the challenge and predisposes them to safe courses of action; they would help the challenger to advance.

\section{Morgenthau on the Moral Qualities}

The political leadership should exhibit four key moral qualities. First, it should exhibit moral willingness. Morgenthau $(1960,184)$ understood moral willingness as the state of being ready to assume the burden of managing international problems, overcome isolationist tendencies, and shoulder the responsibility of assisting other 
states to maintain regional status quo. ${ }^{9}$ The lack of moral willingness - a situation in which "will and mind were not equal to [American] power, responsibility, and opportunity"-would result in a failure to assume international leadership. This demonstration of weakness would in turn invite attack (Morgenthau 1960, 184). Morgenthau $(1948,60)$ was concerned, for instance, that the US would repeat the error committed of the interwar period during the Cold War: the reluctance to assume international leadership in the interwar period created the impression that the US was weak, and thus encouraged Germany and Japan to attack. His concern reached its zenith when the Eisenhower administration sought to ease tensions with the Soviet Union. Morgenthau argued that the Geneva meeting and the policy of nonintervention towards Hungary and Poland were ultimately derived from an enfeebled will and an unwillingness to assume the leadership to stand up to Soviet aggression - this abdication of responsibility left the Europeans alone in the face of the Soviet threat (Morgenthau 1962c, 141, 152). In Morgenthau's view, the 'will to lead' was the first moral prerequisite for international leadership.

Second, Morgenthau (1951, 230, 240) argued that political leadership should exhibit "moral determination". Moral determination was the ability to resolutely exercise international leadership: the leaders evidenced it when they demonstrated a strong commitment to holding the opponent's expansion in check, and sought to fend off challenges through quick response and the overcoming of obstacles (e.g., alliance management, or domestic mobilization). Moral determination was frequently strengthened by a commitment to the American purpose, or a firmly held belief that one was fighting for the right and just cause. In the absence of moral determination, the political leadership would weaken, and ultimately abdicate, the state's leading position. Morgenthau criticized, for instance, that the Truman administration did not demonstrate a strong determination to assert international leadership when the administration was tempted to return immediately after the Second World War (Morgenthau 1951). When they showed weakness in manifesting a moral determination to assert international leadership, political leaders would miss the opportunity to do so.

Third, political leadership should display moral courage. By "courage", Morgenthau (1960, 323, 1962c, 109, 161, 307, 322, 356-8) meant that political leadership must have the ability to stand up to the challenges from the expanding power when faced with the exigencies of national security. To the same extent, it must also evidence the ability to resist domestic pressure-the demands which originated within the Congress or citizenry (public opinion) counseled against the wasting of domestic resources, the increase of taxation, and the sacrifice of life for international commitment. In the absence of moral courage, leadership would tend to appease the aggressor, or accommodate domestic opposition which ultimately privileging domestic demands over international challenges (Herman and Hagan 1998, 129).

Fourth, political leadership should exhibit moral restraint. By moral restraint, Morgenthau (1948, 38, 121, 184-96) meant the ability to exercise self-imposed limits on ends and means. In evidencing it, the actor would feel itself to be bound by

${ }^{9}$ On moral will(ingness), see Morgenthau (1962c, 141). 
rules, recognize the danger of self-righteousness, learn to contain one's universalistic aspirations (e.g., universalistic nationalism), and endeavor to respect the other party's interests and rights. The leading state should not, for instance, show a "crusading spirit" (such as the one which the Truman doctrine evidenced when it called for a democratic crusade against Soviet Union). Nor should it arrogantly equate itself with moral superiority. Rather, political leadership should resist the temptation to depict the contestation as a struggle between virtue and vice, good and evil, humanity, and subhumanity.

The lack of moral restraint was a deadly vice: in defending one's international leadership, the political leadership could easily exceed the original aim. In addition, it could also get easily dragged into adventures and become committed to intervention around the world (e.g., against 'communist' aggression in Southeast Asia). Its moral zeal could result in the use of extreme means and the infliction of excessive harm upon the opponent (whether through nuclear attack or escalation of strategic bombing). The failure to display moral restraint led to unnecessarily large casualties and self-destruction, ultimately "engender[ing] the distortion in judgment which, in the blindness of crusading frenzy, destroys nations and civilizations" (Morgenthau 1978, 11).

These moral qualities-willingness, determination, courage, and restraint-are indispensable if political leaders were to fully assume the responsibilities of international leadership and effectively balance against the opponent's expansion.

\section{Morgenthau on the Practical Qualities}

Political leadership should also display several practical virtues. First, political leadership should exhibit "skill" (Morgenthau 1962a, 313, 1962c, 11). ${ }^{10}$ The leadership should excel at using a wide range of means-establishing alliances, building a community of common interest, striking diplomatic deals with the opponent to buy more time, or waging ideological war-to achieve the end of defending against aggression and maintaining balance of power. In some circumstances, such as the Suez Canal Crisis and Cuban Missile Crisis, the American leadership must evidence the ability to effectively deploy conventional military force (force "rationally employed" as Morgenthau 1962d, 430, called it). In other instances, such as the crisis of the Western alliance after Suez, the leadership must establish how to "exact a higher harmony from the disparate national interests". Morgenthau was also one of the forerunning theorists of economic statecraft. In working within this framework, Morgenthau (1962c, 250-3) exhorted the American leadership to "develop a policy which would make foreign trade a potent instrument of American foreign policy". He argued that instead of allowing American foreign trade policy to be dominated by liberal economic thinking, the US should match the Soviet practice of using economic assistance to enhance its political influence in Asia and Africa. In his view, the political leadership must

${ }^{10}$ On skill, Morgenthau (1960, 290; 1962a, 173-4 (on “technical skill”), 1962c, 121, 283, 315). 
demonstrate the ability of applying the appropriate means to a given situation (and also applying these means in the appropriate manner ${ }^{11}$ ).

If this skill was not displayed, it would not only be impossible to counterbalance the opponent's expanding power and influence, but produce counterproductive results. Morgenthau correctly observed, for instance, that the deployment of military force to conflicts in Lebanon and Vietnam to fight against "communist aggression" was counterproductive. The interventions gave rise to anti-Americanism, because enemies were able to depict them as imperialistic adventure against the seeking of national independence; they provided opportunities to the Soviet Union (and China) to position itself as a supporter of national independence (see Morgenthau 1965; also George and Smoke 1974, 309-58). Indeed, Morgenthau (1970, 176-7) often suggested that the American leadership should learn from their opponent's "combined consistency in the pursuit of objectives with extreme flexibility in the choice of means". In his view, political skill is central to the achievement of balancing against threat.

Second, leaders should exert "leadership" over the legislature. Here, Morgenthau $(1970,166)$ referred to the ability to exercise presidential control over foreign policy by winning support for legislation. The leadership must exhibit certain virtues if the executive and legislative branches of government are to effectively collaborate. If this skill was absent, the leaders would either be defeated in the Congress or be submissive to congressional influences. For example, Wilson's failure to secure support for his vision undermined his attempt to establish American international leadership (Ikenberry 2001, 149-60; Thompson 1960, 211-4).

Third, the leadership should display governance. By governance, Morgenthau meant the ability to exercise supervision over the executive branch/bureaucracies in their implementation of presidential orders, resisting the "new feudalism" - a term used by Morgenthau to refer to the fighting of inter-agency wars, the predominance of parochial interests, and the breakdown of response along organizational lines (Klusmeyer 2010, 403; Lebow 2016, 57). ${ }^{12}$ For Morgenthau, it was essential for the political leadership to be able to direct the executive branches. In his words, the political leadership must, "through the authority of his office" and "the strength of his will", command the executive branch, ensuring the effective implementation of foreign policy decision (Morgenthau 1960, 278).

In the absence of governance, it would ultimately frustrate the attempt to exercise state power effectively or to achieve national objectives. It would also result in a fragmented and inadequate response to challenges. Morgenthau maintained that US leaders in the aftermath of FDR had displayed poor quality in this respect. He expressed the concern, for instance, that during the Truman presidency, the process of "government by committee" became more ingrained: he considered the establishment of inter-departmental committees such as the National Security Council as contributing to a diffusion of central authority (Morgenthau 1960,

\footnotetext{
11 Morgenthau was not only concerned with the problem of which instrument would be used, but also with how it would be used. An example was his harsh criticism on the Eisenhower administration's alliance and aid policy (see e.g. Morgenthau 1970, 178).

12 Morgenthau's favorite example was the Thor-Jupiter controversy, see Armacost (1969).
} 
258-62). If leadership is not exerted over the bureaucracies, governmental fragmentation and dysfunction will make it impossible to take strong and swift action.

Fourth, political leadership entails simultaneously assuming the roles of leader, educator, and orator (Morgenthau 1960, 266). The leaders must be ahead of the people, and must be capable of leading, step by step, towards the commitments that are necessary to defeat the challenger. They must be possessed of the ability to educate public opinion and to inform the people when they are ignorant of the urgent situation (and raise their awareness of the issue). They must be able to persuade the people to act, and have the capacity to impress the audience through the powerful presentation of political facts, thus inspiring them to act (this skill, therefore, entails the mobilization of public opinion and domestic support). They should convey a sense of calm, restrain warlike passions, and enhance the "renunciation of quick and radical solutions" (Morgenthau 1962c, 203). Political leadership, therefore, entails the ability to move the people, unify the nation, and gain public consent for actions that uphold the national interest. Morgenthau's $(1960,332)$ ideals were drawn from Pericles and Demosthenes, and found approximation perhaps only in John F. Kennedy.

In the absence of this quality, the political leadership will either be unable to command public support, or will be forced to rely on "devious means" to mobilize popular support (Morgenthau 1949, 147). The invocation of making the world "safe for democracy", fighting for the "free world", and undertaking "massive retaliation" against aggressors is common reference points in this respect.

\section{American Foreign Policy and World Order in the Trump Presidency Viewed from the Perspective of Morgenthau's Theory}

So far, I have demonstrated that Morgenthau has developed a realist theory of international leadership that is grounded on the qualities of political leadership. However, does it still have relevance to contemporary international relations? Can it help IR scholars understand the orientation of American foreign policy under Trump's presidency, and shed light on the future of international leadership and global order?

Since Donald Trump was elected as US president, there has been a widely voiced concern-which has been particularly pronounced among liberal opinion-that his administration would renounce the responsibilities of US international leadership (Ayres 2017; BBC 2017a, b; Washington Post 2016; Sanger and Perlez 2017; Stubb 2017; Trump 2016b). The liberal vision of the prospect of world order can be traced to three anticipating points. First, the Trump administration's approach to international affairs radically departs from the policies adopted by his predecessors in the aftermath of the Second World War. Whereas (say) the Obama administration, which was a strong champion of the liberal order, was willing to assume the lead in managing global issues through multilateral institutions, the Trump administration has proven to be much more 
reluctant in this respect. Trump described NATO as 'obsolete' (at a time when Europe is under growing pressure from Russia), terminated the TTIP, cut funding for human rights initiatives and withdrew from the Paris Agreement. Second, the liberals argue that Trump has been quite explicit that he will put America first-this means that under Trump's leadership, the US will be abandoning global leadership, turning inward, withdrawing from the world, and retreating from the international arena. ${ }^{13}$ The US is "suiciding" its international leadership and creating vacuums in global leadership on key issues such as climate change, trade, and globalization, For liberals, there is a clear concern that states such as China will step into fill the vacuum. Third, as the US turns inward, chaos and disorder will follow. The liberal international order is coterminus with peace and prosperity. ${ }^{14}$ The erosion of the preexisting world order, which is currently sustained by American leadership, will lead to a disordered and dangerous new world.

Morgenthau's theory of international leadership can assist IR scholars to work within a realist perspective and develop three key insights into the future of America's international leadership and world order.

Morgenthau's first contribution will be critical in character. While the initial claim that Trump does not have any great 'love' for the liberal order and is intent on rolling it back has some grounds, the second and third assertions are questionable. The second liberal assertion seems to make the error of equating Trump's approach with isolationism (at the same time, it collapses the defense of liberal international order into active engagement with world affairs). ${ }^{15}$ From this perspective, Trump's attempt to prevent the draining of American resources, the loss of American jobs, or the entanglement in the web of commitments and agreements is interpreted to signal the abandonment of international leadership. This raises the question of why it is impossible to use a national/unilateral and power-based approach to sustain international leadership and maintain order. The third liberal claim equates the liberal international order with peace, security and prosperity. It accordingly constructs international leadership, exerted through multilateral fora, as the only viable way in which the world can be governed; the post-liberal future, by direct implication, will be chaotic and dark. While moving away from an institutionalized and multilateral approach that places emphasis upon rules and restraints, Trump can also consolidate American power, and uses that national power to manage world order. The grim picture that the liberal theorists of international leadership forecast may not necessarily come true.

\footnotetext{
${ }^{13}$ Susan Rice tweeted, for instance, "the cumulative effect of Trump policies, capped by his foolish, tragic Paris decision = abdication of America's global leadership. Shame!" (BBC 2017b).

${ }^{14}$ The Washington Post (2016), in an editorial, stated that "this [liberal] order is worth saving, and it is worth reminding ourselves why: It generated unprecedented global prosperity, lifting billions of people out of poverty; democratic government, once rare, spread to more than 100 nations; and for seven decades there has been no cataclysmic war among the great powers".

15 "After the post-second world war, the US gave birth to a new world order through the Marshall Plan and the creation of international institutions. It was the driver of peace, prosperity and security, through engagement, nor disengagement" (Stubb 2017).
} 
Second, Morgenthau would establish the basis for a cool-headed analysis of Trump's aspirations (i.e., thinking on international leadership). ${ }^{16}$ So far, liberals have sought to portray Trump and the populist movement as intellectually poor, morally outrageous, and practically impotent. This liberal bias against Trump has made it almost impossible to undertake a realistic assessment.

Morgenthau would be able to use his theoretical tool to undertake an objective, nuanced, analysis. He would observe in general that measured against his standards, Trump is seeking a balance-of-power approach to world order-however, he does not at the same time assume moral leadership for Western democracy and liberty or the moral conviction that underpins a liberal vision of American hegemony. Trump is predisposed to adopt a "muscular approach", which presumes "only economic and military power count" and which "abdicate[s] moral power" (BBC 2017b; Sanger and Perlez 2017; Robinson 2017).

Morgenthau can also offer a detailed analysis that examines whether (and to what extent) Trump displays the qualities that are necessary for him to implement his vision. Intellectually, (a) with regard to political wisdom, Trump views international politics as a competitive arena-the distribution and balance of power. He is, therefore, wary of the current imbalance of power, and has expressed particular concern about the fact that globalization and liberal trade policy has enabled the transfer of power and wealth from the US to China. His claim that "[t]he nationstate remains the true foundation for happiness and harmony" embodies his idea of national interest (Trump 2016a). (b) Trump also has the foresight to recognize that a power shift from the US to China will bring danger. The Trump administration does appreciate a point that liberals frequently overlook: given that economic strength is an essential element of American power, a redistribution of US wealth to other countries will ultimately lead to the loss of American hegemony (Sanger and Perlez 2017). (c) Trump evidences sound judgment to a certain extent. Trump grasps, for instance, that power resources are limited and (for him) that the US has spent too much on cutting greenhouse emissions, with this course of actions often coming at the expense of its military (especially nuclear) force. He recognizes that he must cut funds for climate change and human rights, to enhance US military capability vis-àvis China. The US is also contributing far more to NATO than its allies, and many of whom have been underpaying their bills. He even has some grounds to ask the South Koreans to meet some of the costs of deploying THAAD. (d) It is also noticeable that Trump exhibits deliberative virtues in some places. Trump shows decisiveness in his attempt to free the American hands from the ties of multilateral institutions. While he sometimes appears to be reckless, Trump is nonetheless aware that the American leadership is clearly challenged and that a clear policy shift is necessary if American resources are to be saved from being used for international purposes. His meeting with $\mathrm{Xi}$, along with his suggestion of a face-to-face meeting with Kim, demonstrates that he is willing to take alternative courses of action.

\footnotetext{
${ }^{16}$ Morgenthau would be contemptuous of Trump's presidency, condemning his victory as a 'pathology' of American politics, and as an indication of corruption of 'standards of excellence'. Morgenthau would view Trump as a leader with 'zero virtue'.
} 
Trump also arguably displays several moral characters, each of which further strengthens his own vision. He exhibits a clear willingness and determination to reassert America's leading role within world affairs, as epitomized by his calls to "make America great again". This is also reflected in his attack on the Obama administration for losing the respect of other countries, maintaining that US influence in Asia and the Middle East has been impacted as a result. Trump also has the moral courage to stand up to challenge and to confront exigencies of national security, albeit often in a way that is combative and confrontational. Trump has argued that the Obama administration was too conciliatory to its rivals, maintaining that he would take a more hardline position towards China and Iran. However, it remains unclear whether Trump could show moral restraint. Perhaps, this was evidenced when he exchanged rhetoric with the North Korean leader.

In short, an analysis of Trump's intellectual and moral qualities shows that he does not want the US to withdraw entirely from the world. Rather, Trump is taking an approach to sustaining and reasserting American leadership in a way that is radically different from the liberal one.

Third, Morgenthau's realist theory of international leadership can contribute an assessment of whether Trump will successfully realize his vision. Trump, while roughly possessing the intellectual and moral virtues required for the task, does not yet possess the practical ability to implement this strategy. His inadequate possession of practical ability paralyzes his attempt to effectively execute such a policy. There are few signs, for example, that he can overcome domestic constraint of fully switch from a liberal institution to a power-based strategy. In short, Trump's disastrous lack of practical virtues has resulted in innumerable forms of domestic chaos, each of which has severely undermined his presidency.

With regard to practical skill (the ability to employ the 'right' strategy against the opponent), it should be noted that Trump has displayed some competency in tackling the external challenges-for example, he responded to North Korean provocation by threatening "fire and fury". However, in other instances, Trump has displayed incompetency in building communities of interest and unifying allies. A belligerent speech in Brussel irritated NATO allies, a 'screw you' handshake with the French President and ill-advised comments in the aftermath of a terrorist attack on London have all served to alienate allies.

With regard to leadership, Trump has failed to display any practical virtue in exercising presidential leadership over the Congress. He has struggled to win congressional support for his foreign policy, and even his own party evidences considerable suspicion towards his foreign policy. A recent Senate motion, which was sustained by bipartisan support, forced Trump to extend sanctions against on Russia-Trump was committed to the very opposite policy.

With regard to governance, it is clear that Trump does not possess the practical virtues that would enable him to exercise leadership over the government agencies. After becoming president, Trump has gradually lost control over the execution of his policy. His Chief strategist (Steve Bannon) has resigned. Meanwhile, his Secretary of State (Rex Tillerson) is increasingly pressurized by a 'human resources crisis' in the State Department (BBC 2017a). His Chief of Staff (Reince Priebus) and Communications Director (Anthony Scaramucci) have also departed. His orders 
have been defied (Sally Yates have refused to execute Trump's Muslin-Ban order, and are sacked). Even if Trump wants to ease the tension with Russia, the FBI chief continued to pursue investigation into Trump's connection with Putin until its chief is sacked.

Finally, Trump deeply divides the country. This explains why he has been unable to instill a sense of unity or political momentum. Quite the opposite-Trump appears to be a source of disunity. Amidst rising tensions, even the UN has been forced to intervene and issue a warning on racial conflict. Trump's response to farright activism has also caused considerable unrest within his own administration and party.

In returning to Morgenthau's realist theory of international leadership, one may conclude that even if Trump does have certain intellectual and moral abilities, his lack of practical virtues will ultimately restrict his ability to implement his foreign policy vision.

\section{Conclusion}

This article has contended that Hans Morgenthau can help IR scholars to understand the nature and impact of international leadership. It argues that classical realism provides a theoretical tool that enables a more 'realistic' analysis of the future of world order. It shows the deficiencies of the liberal vision that US withdrawal from the international arena under the Donald Trump presidency will necessarily create chaos and a leaderless world. When perceived from Morgenthau's approach, the world will perhaps be less chaotic than the liberals argue-only if Trump can successfully manage to transform his vision into reality. To accomplish this task, Trump must cultivate in himself certain practical qualities, such as skill, leadership, and governance. In the absence of these virtues, Trump can only fulfill the liberals' prophet.

Acknowledgements I am grateful to the conference organizers for offering an excellent opportunity for sharing my thoughts on the subject and presenting the draft. It is interesting to compare and contrast G. John Ikenberry and Hans Morgenthau's theories of international leadership. Special thanks go to Atimav Acharya, Ben Boulton, Sujian Guo, Pippa Morgan, and Xiaoyu Pu, for their comments and help.

\section{Compliance with Ethical Standards}

Conflict of interest The author declares that there is no competing interest.

Funding In writing this article, I have been supported by the "Program for Young Innovative Research Team in China University of Political Science and Law" (grant number 16CXTD19).

\section{References}

Armacost, M.A. 1969. The Politics of Weapons Innovation: The Thor-Jupiter Controversy. New York: Columbia University Press. 
Ayres, A. 2017. Role Reversal: As the US Steps Back from Global Leadership, India Steps Up. Indian Times. http://indianexpress.com/article/opinion/narendra-modi-role-reversal-as-us-donald-trumpsteps-back-from-global-leadership-india-steps-up-4721707/. Accessed 04 Sept 2017.

Barkawi, T. 1998. Strategy as a vocation: Weber, Morgenthau and modern strategic studies. Review of International Studies 24 (2): 159-184.

Brown, C. 2012. The 'Practical Turn', Phronesis and Classic Realism: Towards a Phronetic International Political Theory? Millennium 40 (3): 439-456.

Byman, D.L., and K.M. Pollack. 2001. Let Us Now Praise Great Men. International Security 25 (4): 107-146.

BBC. 2017a. Trumplomacy: Is Tillerson getting ready for a Rexit. http://www.bbc.com/news/world-uscanada-40756948. Accessed 04 Sept 2017.

BBC. 2017 b. Is Trump abandoning US global leadership. http://www.bbc.com/news/world-us-canada40127896. Accessed 04 Sept 2017.

Cox, M. 2007. Hans J. Morgenthau, Realism, and the Rise and Fall of the Cold War. In Realism Reconsidered, ed. Michael Williams. Cambridge: Cambridge University Press.

Craig, C. 2003. Glimmer of a New Leviathan. New York: Columbia University Press.

Gaskarth, J. 2011. Where would we be without rules? A virtue ethics approach to foreign policy analysis. Review of International Studies 37 (1): 393-415.

George, A.L., and R. Smoke. 1974. Deterrence in American Foreign Policy. New York: Columbia University Press.

Gilpin, R. 1981. War and Change in World Politics. Cambridge: Cambridge University Press.

Gilpin, R. 1988. The Theory of Hegemonic War. The Journal of Interdisciplinary History 18 (4): 591-613.

Greenstein, F.I. 2000. The Presidential Difference: Leadership Style from FDR to Clinton. New York: Free Press.

Herman, M.G., and J.D. Hagan. 1998. International Decision Making: Leadership Matters. Foreign Policy 110: 124-137.

Hoffmann, S. 1987. Janus and Minerva. Boulder: Westview.

Hoy, T. 1958. The Idea of Prudential Wisdom in Politics. Western Political Quarterly 11 (2): 243-250.

Ikenberry, G.J. 1996. The Future of International Leadership. Political Science Quarterly 111 (3): 385-402.

Ikenberry, G.J. 2001. After Victory. Princeton: Princeton University Press.

Ikenberry, G.J. 2011. Liberal Leviathan. Princeton: Princeton University Press.

Jervis, R. 1984. Hans Morgenthau, Realism, and the Scientific Study of International Politics. Social Research 61 (4): 853-876.

Keohane, N.O. 2005. On Leadership. Perspectives on Politics 3 (4): 705-722.

Kindleberger, C.P. 1981. Dominance and Leadership in the International Economy. International Studies Quarterly 25 (2): 242-254.

Kindleberger, C.P. 1987. The world in depression, 1929-1939. Chicago: University of California Press.

Klusmeyer, D.B. 2010. Hans Morgenthau and Republicanism. International Relations 24 (4): 389-413.

Krasner, S.D. 1976. State Power and the structure of International Trade. World Politics 28 (3): 317-347.

Lake, D.A. 1993. Leadership, Hegemony and the International Economy: Naked Emperor or Tattered Monarch with Potential? International Studies Quarterly 37 (4): 459-489.

Lang, A. 2004. Political Theory and International Affairs: Hans J. Morgenthau on Aristotle's The Politics. London: Praeger.

Lang, A. 2007. Morgenthau, Agency, and Aristotle. In Realism Reconsidered, ed. Michael Williams. Cambridge: Cambridge University Press.

Lang, A. 2013. Phronesis, Morgenthau and Diplomacy. E-IR. http://www.e-ir.info/2013/11/07/phronesismorgenthau-and-diplomacy. Accessed 04 Sept 2017.

Lebow, R.N. 2003. The Tragic Vision of Politics. Cambridge: Cambridge University Press.

Lebow, R.N. 2009. The Ancient Greeks and Modern Realism. In Political Realism, ed. Duncan Bell. Oxford: Oxford University Press.

Lebow, R.N. 2016. Hans Morgenthau and the Purpose of American Politics. Ethics and International Affairs 30 (1): 55-62.

MacIntyre, A. 2007. After Virtue. London: Bloomsbury.

McCourt, D.M. 2012. What's at stake in the Historical Turn? Theory, Practice and Phronesis in International Relations. Millennium 41 (1): 23-42. 
McDermott, R., and P.K. Hatemi. 2014. The Study of International Politics in the Neurobiological Revolution: A Review of Leadership and Political Violence. Millennium 43 (1): 92-123.

Mearsheimer, J.J. 2001. The tragedy of great power politics. New York: WW Norton \& Company.

Modelski, G. 1978. The Long Cycle of Global Politics and the Nation-State. Comparative Studies in Society and History 20: 214-235.

Modelski, G. 1987. Long cycles in world politics. Basingstoke: Macmillan.

Molloy, S. 2009. Aristotle, Epicurus, Morgenthau and the Political Ethics of the Lesser Evil. Journal of International Political Theory 5 (1): 94-112.

Morgenthau, H.J. 1948. Politics among Nations, 1st ed. New York: Alfred A. Knopf.

Morgenthau, H.J. 1949. Conduct of American Foreign Policy. Parliamentary Affairs 3: 147-161.

Morgenthau, H.J. 1951. In Defense of the National Interest. New York: Alfred A. Knopf.

Morgenthau, H.J. 1952. What is the National Interest of the US? Annals of the American Academy of Political and Social Science 282: 1-7.

Morgenthau, H.J. 1954. Politics among Nations, 2nd ed. New York: Alfred A. Knopf.

Morgenthau, Hans. 1955. Foreign Policy: The Conservative School. World Politics 7 (2): 284-292.

Morgenthau, H.J. 1960. The Purpose of American Politics. New York: Alfred A. Knopf.

Morgenthau, H.J. 1962a. Decline of Democratic Politics. Chicago: The University of Chicago Press.

Morgenthau, H.J. 1962b. The Impasse of American Foreign Policy. Chicago: The University of Chicago Press.

Morgenthau, H.J. 1962c. The Restoration of American Politics. Chicago: The University of Chicago Press.

Morgenthau, H.J. 1962d. Cuba-The Wake of Isolation. Commentary 34 (5): 427-430.

Morgenthau, H.J. 1965. Vietnam and the US. Washington, D.C.: Public Affairs Press.

Morgenthau, H.J. 1969. A New Foreign Policy for the United States. New York: Praeger.

Morgenthau, H.J. 1970. Truth and Power. London: Pall Mall.

Morgenthau, H.J. 1978. Politics among Nations, 3rd ed. New York: Alfred A. Knopf.

Murray, A.J. 1996. The Moral Politics of Hans Morgenthau. Review of Politics 58 (1): 81-108.

Myers, R.J. 1997. Hans Morgenthau's Realism and American Foreign Policy. Ethics \& International Affairs 11: 253-270.

Nobel, J.W. 1995. Morgenthau's Struggle with Power: The Theory of Power Politics and the Cold War. Review of International Studies 21 (1): 61-85.

Nye Jr., Joseph S. 2008. Recovering American Leadership. Survival 50 (1): 55-68.

Organski, A.F., and J. Kugler. 1981. The War Ledger. Chicago: University of Chicago Press.

Quinn, A. 2011. The Art of Declining Politely: Obama's Prudent Presidency and the Waning of American Power. International Affairs 87 (4): 803-821.

Ringmar, E. 2014. The Search for Dialogue as Hindrance to Understanding. International Theory 6 (1): $1-27$.

Robinson, E. 2017. Trump is abdicating all the country's moral power. https://www.washingtonpost.com/ opinions/trump-is-abdicating-all-the-countrys-moral-power/2017/06/01/709ad08a-4705-11e7-98cdaf64b4fe2dfc_story.html. Accessed 4 Sept 2017.

Ruggie, J.R. 1982. International Regimes, Transactions, and Change: Embedded Liberalism in the Postwar Economic Order. International Organization 36 (2): 379-393.

Sanger, D.E., and Perlez, J. 2017. Trump Hands the Chinese a Gift: The Chance for Global Leadership. The New York Times. https://www.nytimes.com/2017/06/01/us/politics/climate-accord-trump-chinaglobal-leadership.html. Accessed 04 Sept 2017.

Scheuerman, W.E. 2009. Hans Morgenthau. Cambridge: Polity.

See, J.W. 2001. A Prophet without Honor: Hans Morgenthau and the War in Vietnam, 1955-1965. Pacific Historical Review 70 (3): 419-447.

Stubb, A. 2017. It's Europe's turn to fill the global power vacuum. The Financial Times. https://www.ft. com/content/74903c98-f9ea-3c64-9f3f-b864710891dc. Accessed 04 Sept 2017.

The Washington Post. 2016. The Liberal International Order is under fire. The US Must Defend It. https:// www.washingtonpost.com/opinions/the-liberal-international-order-is-under-fire-the-united-statesmust-defend-it/2016/05/21/dd5a01c6-1eae-11e6-9c81-4be1c14fb8c8_story.html. Accessed 04 Sept 2017.

Thompson, K.W. 1960. Political Realism and the Crisis of World Politics. Princeton: Princeton University Press.

Thompson, K.W. 1984. The Dilemmas and Antinomies of Leadership. Presidential Studies Quarterly 14 (1): $35-42$. 
Trump, D. 2016a. Donald Trump's Foreign Policy Speech. The New York Times. https://www.nytimes. com/2016/04/28/us/politics/transcript-trump-foreign-policy.html?mcubz=0. Accessed 03 June 2016.

Trump, D. 2016b. Donald Trump's New York Times Interview. The New York Times. https://www. nytimes.com/2016/11/23/us/politics/trump-new-york-times-interview-transcript.html?mcubz=0. Accessed 04 Sept 2017.

Turner, Stephen. 2009. Hans J. Morgenthau and the Legacy of Max Weber. In Political thought and international relations, ed. Duncan Bell. Oxford: Oxford University Press.

Turner, Stephen P., and Regis A. Factor. 1984. Max Weber and the Dispute over Reason and Value. London: Routledge.

Williams, Michael C. 2005. Limits of Realism. Cambridge: Cambridge University Press.

Yan, X. 2016. Political Leadership and Power Redistribution. Chinese Journal of International Politics 9 (1): $1-26$.

Young, O.R. 1991. Political Leadership and Regime Formation: On the Development of Institutions in International Society. International Organization 45 (3): 281-308.

Biao Zhang obtained his degrees from Peking, Warwick, and Exeter. Having successfully defended his thesis on The Concept of Reason in International Relations 1919-2009 (passed without correction), Biao joined CUPL as a lecturer in IR. He is interested in IR theory and China-EU relations (with a special focus on China-UK relations). 